\title{
Effect of employee demographic characteristics and job characteristics on job satisfaction among employees in the banking industry: A case of commercial banks in Nakuru Town, Kenya
}

\author{
Elizabeth Wanjiru Ngigi ${ }^{1}$, Dinah Jeruto Kipkebut ${ }^{2}$, \\ ${ }^{1}$ Faculty of Commerce, Department of Business Administration \\ Egerton University, Kenya \\ ${ }^{2}$ Lecturer, Faculty of Commerce, Department of Business Administration \\ Egerton University, Kenya
}

\begin{abstract}
The banking industry in Kenya is operating in an environment that is becoming increasingly complex due to increased competition, rapid technological changes, globalisation and growth of alternative banking institutions. In order for the banks to achieve success and to satisfy their customer needs, they must attract and retain a satisfied workforce as a source of competitive advantage. The objective of the present study is to examine the effects of demographic characteristics (age, gender, marital status, education, tenure and bank sector) and job characteristics (namely; job autonomy, job variety, role stress, co-worker and supervisory support) on job satisfaction among employees in commercial banks in Nakuru Town in Kenya. The sample of the study consisted of 126 employees drawn from a population of 180 employees from three (3) locally owned banks and five (5) foreign-owned banks. Questionnaires were used to collect data which were analysed using inferential statistics which included Independent Samples TTest, One Way Analysis Of Variance (ANOVA), Pearsons Correlation and Multiple Regression analysis. The results showed that (a) demographic characteristics partially influenced job characteristics and job satisfaction; (b) Job autonomy, job variety, co-worker and supervisory support had significant, positive effects on job satisfaction; (c) Role stress did not have a significant effect on job satisfaction. The study recommends that bank managers adopt various managerial interventions in order to create a pleasant and supportive work environment in which job satisfaction will thrive.
\end{abstract}

Key words: Job satisfaction, Demographic characteristics, supervisory support, job autonomy, Kenya.

\section{Council for Innovative Research}

Peer Review Research Publishing System

Journal: International Journal of Management \& Information Technology

Vol. 9, No. 3

editor@cirworld.com

www.cirworld.com, member.cirworld.com 


\section{INTRODUCTION}

Several studies have shown that job satisfaction has significant positive effect on employee performance and job satisfaction, and negatively influences employee turnover (Lambert \& Paoline, 2008). Satisfied employees have been found to be happy, industrious and dedicated to their work resulting in enhanced productivity and attainment of organizational goals (Shah \& Jalees, 2004; Saari \& Judge, 2004; Dessler, 2005).

The present day business environment, within which banks operate, has become increasingly turbulent and complex. This is as a result of globalisation, increased competition and rapid technological change, which is presenting new challenges and new opportunities for the banking industry. Therefore, the success of banks in the "grow-or-die" market place is dependent on satisfied and committed employees (Shrivastava \& Purang, 2009). Job satisfaction, therefore, is very important in banks because if employees are not satisfied, their work performance, productivity, commitment as well as the interpersonal relationships among the management and their subordinates tend to be lowered (Greenberg \& Baron, 1996; Saleem, Majeed \& Aziz, 2013). Lack of job satisfaction resulting in turnover among bank employees cannot be taken lightly due to the associated costs which include recruitment costs, loss of well trained, experienced employees, increase in overtime payment, lost productivity and declining sales (Mbah. \& Ikemefuna, 2012). Loss of the employees means loss of intellectual asset that will take a huge budget to replace, ultimately affecting organizational costs and eventually the profits.

\section{STATEMENT OF THE PROBLEM}

Many banking organizations are reporting high staff turnover due to factors associated with lack of job satisfaction. Griffeth \& Hom, (2004) reported that lack of job satisfaction and turnover intention among employees cannot be taken lightly since these employees have undergone training at a high level. Therefore, the loss of employees means loss of intellectual asset that will take a huge budget to replace. Such losses significantly affect organizational costs and eventually the profits. Further, since banking institutions are the backbone of a nation's economy, unsatisfied employees will not be able to realize organizational objectives therefore making the banks perform below expectations thus affecting the growth and performance of an entire economy (Shrivastava \& Purang, 2009). The banking industry in Kenya, therefore, cannot afford to lose skilled employees in this era that is full of market challenges such as; competition, innovation, growth of alternative banking institutions and money mobilization in the global arena. Finnegan (2010) noted that organisations, banks included, that meet employee remuneration needs, may not be able to stem job dissatisfaction and high employee turnover due to other work-related factors. It is for these reasons that this research seeks to find out the effect of employee demographic characteristics and job characteristics on employee job satisfaction in Commercial Banks in Nakuru town, Kenya.

\section{LITERATURE REVIEW}

Locke (1979) defined job satisfaction as a pleasurable or positive emotional state resulting from the appraisal of one's job experiences. Spector (1997) defined job satisfaction as an attitudinal variable that measures how a person feels about his or her job, including different facets of the job. Gentile \& Mcfarlin (1991) defined job satisfaction as an overall feeling about one's job or career in terms of specific facets of the job or careers (e.g. compensation, autonomy, co-workers).

Herzberg (1966) found that job satisfaction was a multidimensional concept consisting of intrinsic job content factors (such as feelings of accomplishment, achievement, recognition, work itself possibility of advancement and responsibility) and extrinsic job context factors (such as salary, job security, physical working conditions, co-worker and supervisory support, company policies and administration).

Various studies have been carried out relating job satisfaction to different work-related characteristics such as task variety, autonomy, feedback, role conflict, role ambiguity, work overload, co-worker and supervisory support (Hackman \& Lawler, 1971; Lambert, 2004;Seston, Hassell, Ferguson \& Hann, 2009). The variables of the study are as follows:

\subsection{DEMOGRAPHIC CHARACTERISTICS}

Employees' demographic characteristics are some of the most commonly used variables in relation to organisational commitment and job satisfaction although some studies have found inconsistent results (Mathieu \& Zajac, 1990;AlQarioti and Al-Enezi, 2004). Demographic characteristics that have been found to have stable relationship with turnover intentions and job satisfaction in past research include age, job tenure, level of education, level of income, and job category (Price \& Mueller, 1986; Khan \& Khan, 2011).

Age: Studies have found a significant positive relationship between age and job satisfaction (Griffin, 1998; Nestor \& Leary, 2000). In a survey study of 263 employees of a Caribbean university, Brown \& Sargeant (2007) found that older workers (i.e. aged 46 years and above) had higher levels of overall, intrinsic, and extrinsic job satisfaction and organisational commitment than their younger colleagues (i.e. aged 26 to 35 years).

Marital status: Fetsch \& Kennington (1997) found a relationship between marital status and job satisfaction levels. The study found that both divorced and married employees were more satisfied with their jobs than employees who were never married, remarried, or widowed. Clark, Oswald \& Warr (1996)also found significant differences in that married and widowed employees reported a higher level of job satisfaction compared to single and divorced 
employees. On the other hand, Bader, Hashim \& Zaharim (2013) found that married employees had lower levels of job satisfaction than employees who were divorced or widowers.

Gender: Studies have found conflicting results in the relationship between job satisfaction levels and gender (Bowen et al, 1994. Some studies have found insignificant relationship between gender and job satisfaction (Nestor \& Leary, 2000; Bader et al., 2013). Dhanapal et al. (2013), in a study of 100 academics, did not find any significant gender differences in job satisfaction. On the other hand, some studies have found significant relationship between gender and job satisfaction. Riggs \& Beus (1993) found that job satisfaction enhanced among female agents when their areas of responsibility increased. Kipkebut (2013) found that female employees in Kenyan universities were more dissatisfied with the intrinsic aspects of their jobs as compared to their male colleagues.

Education: Various studies have found that education was negatively related to job satisfaction, and positively related to turnover intentions (Mathieu \& Zajac, 1990; Eskildsen, Kristensen \& Westlund, 2004). Mowday et al., (1982) reported that the inverse relationship may result from the fact that highly educated employees have higher expectations that the organisation may be unable to meet resulting in the loss of commitment and job satisfaction. Clark et al (1996) found that highly educated employees were more dissatisfied with their jobs unlike employees with lower levels of education.

Tenure: Studies have found significant relationship between tenure and job satisfaction. Nestor \& Leary (2000) found that increase in work experience resulted in increased intrinsic and overall job satisfaction. On the other hand, Jegan \& Gnanadhas (2011) found that job satisfaction of bank employees with a long duration of working experience reported a higher level of job satisfaction than employees with less experience.

\subsection{JOB CHARACTERISTICS}

Work environments are not just tangible, physical structures but are also composed of social and psychological factors (Lambert, 2004). Job characteristics refer to variables that describe characteristics of jobs performed by employees which creates conditions for high work motivation, satisfaction, and performance (Hackman \& Oldham, 1980). Studies have shown that employees exhibit high levels of commitment and job satisfaction when they perform challenging and complex jobs characterised by factors such as skills variety, autonomy, and feedback among others (Sims et al., 1976; Hackman \& Oldham, 1980; Mathieu \& Zajac, 1990; Meyer \& Allen, 1997)

Co-worker Support: Co-worker support has the ability to make a working environmenta pleasant or unpleasant place to work. Sloan (2012) reported that workers who experience mistreatment at work may suffer significant consequences such as psychological distress, job dissatisfaction, and problems with substance abuse. Further, Lacy \& Sheehan (1997) noted that employees who have satisfactory professional interaction with their colleagues at work, who receive respect from fellow employees, and have confidence and trust in their colleagues, tended to be more satisfied with their jobs than employees with poor co-worker support. Bonache (2005) reported that social support from co-workers serve as a resource that affects job satisfaction.

Supervisory Support: Studies have shown that employees who perceive themselves to be in a supportive relationship with their supervisor have low occupational stress, higher satisfaction and organizational commitment than those who do not perceive themselves to be in supportive relationships with their supervisor (Brough \& Pears, 2004; McCormack et al., 2006). Studies have shown that employees are more likely to view their jobs and employing organisations in a more favourable light if they are provided with positive support from their supervisors (Lambert, 2004; Lambert et al., 2007).

Job Autonomy: Job autonomy is the degree to which a job provides substantial freedom, independence and discretion to the individual in scheduling the work and in determining the procedure to be used in carrying it out (Hackman \& Oldham, 1980). Job autonomy empowers employees through access to information, support, resources and growth opportunities that directly affect their level of control (Vidal et al., 2007). Lambert (2003) found that job autonomy had positive effects on both job satisfaction and organisational commitment among correctional staff members.

Role Stress: Role stress is the extent to which employees are tense, frustrated, worried, emotionally exhausted and do not feel happy working in the organization (Bemana, 2013; Lambert \& Paoline, 2008). Role stress can be experienced in jobs that lack adequate variety and that avail employees with less information about their roles resulting to role ambiguity and lack of role clarity (Judge at al., 2001). High levels of role stressors are likely to cause employees to perceive the organization as unsupportive and unfair, thus diminishing their affective commitment and job satisfaction (Addae \& Parboteeah, 2008).

Job variety: Job variety is the degree of variation of the job (Price \& Mueller, 1986). Studies have shown that employees are unlikely to enjoy repetitive, boring jobs that provide little opportunity for mental stimulation or growth (Curry et al., 1986; Lambert 2004; Lambert et al., 2007). Lambert (2003) found that job variety had positive effects on both job satisfaction and organisational commitment among correctional staff members. From the reviewed literature, the following hypotheses are proposed:

$\mathrm{H}_{0}$ 1: There are no differences in job characteristics and job satisfaction based on demographic characteristics, namely: age, gender, marital status, education, job tenure and position tenure

$\mathrm{H}_{\mathrm{o}} 2$ : Job characteristics do not have any significant effect on job satisfaction. 
$\mathrm{H}_{0} 3$ : The combined effects of employee demographic characteristics and job characteristics do not have any significant effect on job satisfaction.

\section{METHOD}

This research paper is based on a cross-sectional study from a random sample of employees from eight commercial banks in Nakuru Town, Kenya. The population of the study consisted of all 180 employees working in the eight commercial banks. Questionnaires were distributed to a sample of 140 employees in the following categories: Heads of sections, Middle-management and Clerical through a 'drop and pick' method. From the 140 bank employees who participated in the study, 130 responded to the survey giving an overall response rate of $93 \%$. Screening of the data reduced the sample to 126 respondents. The description of the respondents is presented in Table 1 below.

Table 1: Summary of demographic characteristics of the respondents

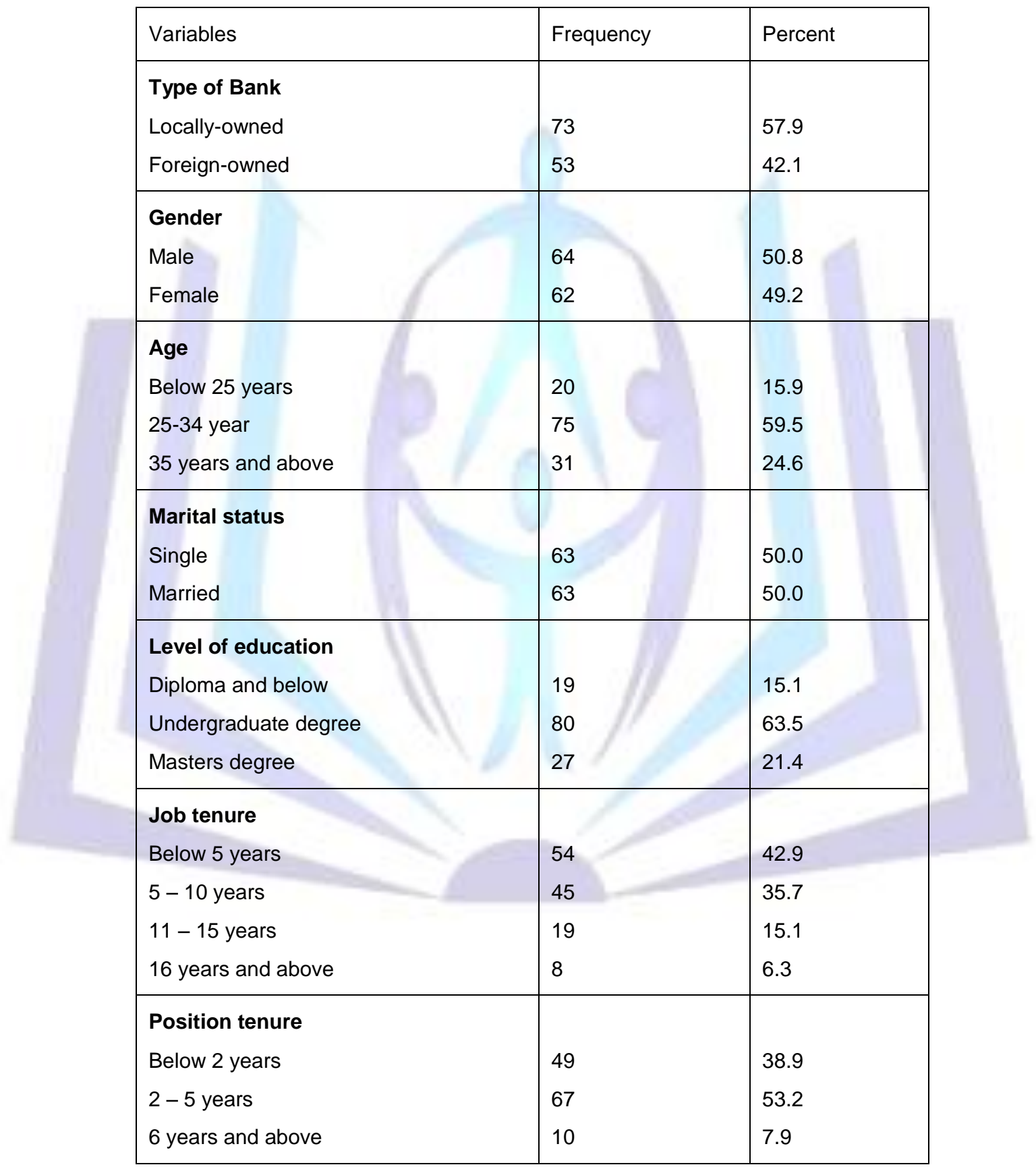

\section{Measurement of the variables}

Following extensive review of the literature, the questionnaire to collect data for the study was developed and measured on a 5-point likert scale from strongly agree to strongly disagree, where point-1 indicate Strongly Disagree, 2 - Disagree, 3 - Uncertain, 4 - Agree and 5 - Strongly Disagree. Cronbach's alpha reliability coefficients were computed for each variable and the results showed acceptable reliability for all measures as follows: job satisfaction 
( $\alpha=0.867)$; job variety $(\alpha=0.730)$; job autonomy $(\alpha=0.826)$; role stress $(\alpha=0.849)$; co-worker support $(\alpha=0.834)$; and supervisory support $(\alpha=0.825)$. The demographic characteristics are as follows: age, gender, marital status, job tenure, position tenure, education, and bank sector (locally-owned and foreign-owned banks).

\section{RESULTS}

The testing of hypotheses was subjected to statistical analysis as shown below. Independent samples t-tests and oneway Analysis of Variance (ANOVA) was carried out to test Hypothesis One. Pearson Correlation analysis was carried out to test Hypothesis Two. Finally, multiple regression analyses were conducted to test Hypothesis Three.

a) Results of Independent samples t-tests and one-way Analysis of Variance (ANOVA)

$\mathrm{H}_{0}$ 1: There are no differences in job characteristics and job satisfaction based on employee demographic characteristics, namely: age, gender, marital status, education, job tenure, position tenure and bank sector.

a) Gender

Table 2: Results of Independent Samples t-test exploring differences in job characteristics and job satisfaction based on gender

\begin{tabular}{|c|c|c|c|c|c|c|}
\hline Variables & $\begin{array}{l}\text { Gender of } \\
\text { respondent }\end{array}$ & $\mathbf{N}$ & Mean & $\begin{array}{l}\text { Std. } \\
\text { Deviation }\end{array}$ & t-value & $\begin{array}{l}\text { Sig. (2- } \\
\text { tailed) }\end{array}$ \\
\hline Job autonomy & $\begin{array}{l}\text { Male } \\
\text { Female }\end{array}$ & $\begin{array}{l}64 \\
62\end{array}$ & $\begin{array}{l}12.97 \\
12.76\end{array}$ & $\begin{array}{l}3.64 \\
3.91\end{array}$ & 0.313 & 0.755 \\
\hline Co-worker support & $\begin{array}{l}\text { Male } \\
\text { Female }\end{array}$ & $\begin{array}{l}64 \\
62\end{array}$ & $\begin{array}{l}15.02 \\
14.94\end{array}$ & $\begin{array}{l}2.81 \\
3.69\end{array}$ & 0.137 & 0.891 \\
\hline Supervisory support & $\begin{array}{l}\text { Male } \\
\text { Female }\end{array}$ & $\begin{array}{l}64 \\
62\end{array}$ & $\begin{array}{l}11.48 \\
11.24\end{array}$ & $\begin{array}{l}2.22 \\
2.53\end{array}$ & 0.572 & 0.568 \\
\hline Job variety & $\begin{array}{l}\text { Male } \\
\text { Female }\end{array}$ & $\begin{array}{l}64 \\
62\end{array}$ & $\begin{array}{l}11.38 \\
10.65\end{array}$ & $\begin{array}{l}2.32 \\
2.76\end{array}$ & 1.607 & 0.111 \\
\hline Role stress & $\begin{array}{l}\text { Male } \\
\text { Female }\end{array}$ & $\begin{array}{l}64 \\
62\end{array}$ & $\begin{array}{l}19.72 \\
18.98\end{array}$ & $\begin{array}{l}5.75 \\
6.62\end{array}$ & 0.666 & 0.507 \\
\hline Job satisfaction & $\begin{array}{l}\text { Male } \\
\text { Female }\end{array}$ & $\begin{array}{l}64 \\
62\end{array}$ & $\begin{array}{l}9.88 \\
9.75\end{array}$ & $\begin{array}{l}2.89 \\
3.07\end{array}$ & 0.227 & 0.821 \\
\hline
\end{tabular}

The results in Table 1 show that there were no statistically significant differences in the means scores of job characteristics and job satisfaction based on gender. This suggests that male and female employees were equally satisfied with their jobs and the work environment.

b) Marital status

Table 3: Results of Independent Samples t-test exploring differences in job characteristics and job satisfaction based on marital status

\begin{tabular}{|l|l|l|l|l|l|l|}
\hline & Marital status & $\mathrm{N}$ & Mean & $\begin{array}{l}\text { Std. } \\
\text { Deviation }\end{array}$ & $\mathrm{T}$ & $\begin{array}{l}\text { Sig. (2- } \\
\text { tailed) }\end{array}$ \\
\hline Job autonomy & Single & 63 & 12.95 & 3.56 & 0.260 & 0.796 \\
& Married & 63 & 12.78 & 3.97 & & \\
\hline Co-worker support & Single & 63 & 15.02 & 2.87 & 0.136 & 0.892 \\
& Married & 63 & 14.94 & 3.63 &
\end{tabular}




\begin{tabular}{|l|l|l|l|l|l|l|}
\hline Supervisory support & Single & 63 & 11.13 & 2.47 & -1.128 & 0.261 \\
& Married & 63 & 11.60 & 2.27 & & \\
\hline Job variety & Single & 63 & 10.63 & 2.59 & -1.680 & 0.096 \\
& Married & 63 & 11.40 & 2.51 & & \\
\hline Role stress & Single & 63 & 18.06 & 5.80 & -2.395 & 0.018 \\
& Married & 63 & 20.65 & 6.32 & & \\
\hline Job satisfaction & Single & 63 & 9.48 & 3.08 & -1.292 & 0.199 \\
& Married & 63 & 10.16 & 2.84 & & \\
\hline
\end{tabular}

The results in Table 3 shows that with the exception of role stress, the mean scores of job autonomy, co-worker support, supervisory support, job variety and job satisfaction did not differ significantly among married and single employees $(p>0.05)$. The analysis has shown that married respondents have higher mean scores $(M=20.65)$ than single respondents $(M=18.06, p=0.018)$. This shows that married employees experienced higher role stress than single employees.

\section{c) Bank sector}

Table 4: Results of Independent Samples t-test exploring differences in job characteristics and job satisfaction on the basis of the bank sector

\begin{tabular}{|l|l|l|l|l|l|l|}
\hline & Bank sector & N & Mean & $\begin{array}{l}\text { Std. } \\
\text { Deviation }\end{array}$ & T & $\begin{array}{l}\text { Sig. (2- } \\
\text { tailed) }\end{array}$ \\
\hline Job autonomy & Locally-Owned bank & 73 & 13.22 & 3.80 & 1.244 & 0.216 \\
& Foreign-Owned bank & 53 & 12.38 & 3.68 & \\
\hline Co-worker support & Locally-Owned bank & 73 & 14.38 & 3.44 & -2.441 & 0.016 \\
& Foreign-Owned bank & 53 & 15.79 & 2.82 & & \\
\hline Supervisory support & Locally-Owned bank & 73 & 11.53 & 2.18 & 0.939 & 0.349 \\
\hline Job variety & Foreign-Owned bank & 53 & 11.13 & 2.62 & & \\
\hline Role stress & Locally-Owned bank & 73 & 10.84 & 2.74 & -0.926 & 0.357 \\
& Foreign-Owned bank & 53 & 11.26 & 2.30 & & \\
\hline Job satisfaction & Locally-Owned bank & 73 & 18.77 & 5.71 & -1.261 & 0.210 \\
& Foreign-Owned bank & 53 & 20.17 & 6.74 & & \\
\hline
\end{tabular}

The results in Table 4 shows that with the exception of co-worker support, the mean scores of job autonomy, role stress, supervisory support, job variety and job satisfaction did not differ significantly among respondents in locallyowned and foreign-owned banks $(p>0.05)$. The analysis has shown that respondents from foreign-owned banks have higher mean scores for co-worker support $(M=15.79)$ than respondents from locally-owned banks $(M=14.38, p=$ 0.018). This suggests that employees from foreign-owned banks are more satisfied with the relationship with their colleagues than employees from locally-owned banks.

\section{d) Age}


Table 5: Results of ANOVA exploring differences in job characteristics and job satisfaction based on the age of respondents

\begin{tabular}{|l|l|l|l|l|l|}
\hline & $\begin{array}{l}\text { Below 25 } \\
\text { years }\end{array}$ & 25-34 years & $\begin{array}{l}\text { 35 years and } \\
\text { above }\end{array}$ & F (ANOVA) & Sign \\
\cline { 2 - 5 } & Mean & Mean & Mean & \\
\hline Job autonomy & 12.40 & 12.72 & 13.52 & 0.670 & 0.513 \\
\hline Co-worker support & 14.75 & 15.04 & 14.97 & 0.062 & 0.940 \\
\hline Supervisory support & 10.65 & 11.37 & 11.81 & 1.457 & 0.237 \\
\hline Job variety & 10.35 & 11.11 & 11.23 & 0.823 & 0.447 \\
\hline Role stress & 20.10 & 18.28 & 21.48 & 3.233 & 0.043 \\
\hline Job satisfaction & 9.80 & 9.96 & 9.48 & 0.277 & 0.759 \\
\hline
\end{tabular}

The results in Table 5 has shown that, with the exception of role stress, the mean scores of job autonomy, co-worker support, supervisory support, job variety, and job satisfaction did not differ significantly based on the age of the respondents $(p>0.05)$. The results shows that there were statistically significant differences in the mean scores of role stress among the three age Groups $(F=3.233, p=0.043)$. The results have shown that the mean scores for respondents aged 35 years and above $(M=21.48)$ were significantly higher than those aged 25 to 34 years ( $M=$ 18.28). This suggests that respondents aged 35 years and above were more affected by role stress than respondents aged 25 to 34 years.

\section{e) Job tenure}

Table 6: Result of ANOVA exploring differences in job characteristics and job satisfaction based on job tenure

\begin{tabular}{|l|l|l|l|l|l|l|}
\hline & $\begin{array}{l}\text { Below } \\
\text { years }\end{array}$ & $\begin{array}{l}\mathbf{6 - 1 0} \\
\text { years }\end{array}$ & $\begin{array}{l}\mathbf{1 1 - 1 5} \\
\text { years }\end{array}$ & $\begin{array}{l}\mathbf{1 6} \text { years and } \\
\text { above }\end{array}$ & F (ANOVA) & Sign \\
\cline { 2 - 6 } & Mean & Mean & Mean & Mean & \\
\hline Job autonomy & 13.26 & 11.84 & 12.95 & 15.75 & 3.016 & 0.033 \\
\hline Co-worker support & 14.70 & 15.51 & 13.53 & 17.25 & 3.244 & 0.024 \\
\hline Supervisory support & 11.52 & 11.33 & 10.21 & 13.25 & 3.455 & 0.019 \\
\hline Job variety & 10.96 & 10.91 & 10.63 & 12.88 & 1.599 & 0.193 \\
\hline Role stress & 19.72 & 18.67 & 20.26 & 18.63 & 0.418 & 0.740 \\
\hline Job satisfaction & 10.08 & 9.72 & 8.53 & 11.38 & 2.120 & 0.101 \\
\hline
\end{tabular}

The results of one-way ANOVA in Table 6, shows that the mean scores of job variety, role stress and job satisfaction did not differ significantly on the basis of job tenure $(p>0.05)$. The analysis has shown that there were significant differences in the mean scores of job autonomy based on years worked in the bank $(F=3.016, P=0.033)$. The results show that respondents who had worked in the bank for 16 years and above had significantly higher mean scores $(M=15.75)$ than respondents who had worked between 6 to10 years $(M=11.84)$.

The analysis has shown that the mean scores for co-worker support differed significantly on the basis of the years worked in the bank $(F=3.244, \mathrm{P}=0.024)$. The results have shown that respondents who had worked in the bank for 16 years and above had significantly higher mean scores $(M=17.25)$ than respondents who had worked between 11 to15 years $(M=13.53)$.

The analysis has shown that there were significant differences in the mean scores of supervisory support based on years worked in the bank $(F=3.455, \mathrm{P}=0.019)$. The results show that respondents who had worked in the bank for 16 years and above $(M=13.25)$ had significantly higher mean scores for supervisory support than respondents who had worked between 11 to 15 years $(M=10.21)$. 


\section{f) Position tenure}

Table 7: Results of ANOVA exploring differences in job characteristics and job satisfaction based on position tenure

\begin{tabular}{|l|l|l|l|l|l|}
\hline & Below 2 years & 2-5 years & $\begin{array}{l}\text { 6 years and } \\
\text { above }\end{array}$ & F (ANOVA) & Sign \\
\cline { 2 - 5 } & Mean & Mean & Mean & \\
\hline Job autonomy & 13.16 & 12.58 & 11.30 & 0.407 & 0.667 \\
\hline Co-worker support & 14.98 & 15.19 & 13.50 & 1.178 & 0.311 \\
\hline Supervisory support & 11.61 & 11.48 & 9.40 & 3.952 & 0.022 \\
\hline Job variety & 11.29 & 11.09 & 9.20 & 2.891 & 0.050 \\
\hline Role stress & 19.29 & 18.85 & 23.10 & 2.100 & 0.127 \\
\hline Job satisfaction & 10.65 & 9.36 & 8.90 & 3.257 & 0.042 \\
\hline
\end{tabular}

The results of one-way ANOVA in Table 7 shows that the mean scores of job autonomy, co-worker support and role stress did not differ significantly based on position tenure $(p>0.05)$. The analysis has shown that there were significant differences in the mean scores of supervisory support based on position tenure $(F=3.952, p=0.022)$. The results show that respondents who had been in the same position for 6 years and above had significantly lower mean scores $(M=9.40)$ than respondents who had been in the same position for 2-5 years $(M=11.48)$ and for less than 2 years $(M=11.61)$.

The analysis has shown that there were significant differences in the mean scores of job variety based on position tenure $(F=2.891, p=0.050)$. The results have shown that respondents who had been in the same position for 6 years and above had significantly lower mean scores $(M=9.20)$ than respondents who had been in the same position for $2-5$ years $(M=11.09)$ and for less than 2 years $(M=11.29)$.

The analysis has shown that there were significant differences in the mean scores of job satisfaction based on position tenure $(F=3.257, P=0.042)$. The results show that respondents who had worked in the same position for 6 years and above had significantly lower mean scores $(M=8.90)$ than respondents who had been in the same position for 2-5 years $(M=9.36)$ and for less than 2 years $(M=10.65)$.

\section{g) Level of education}

Table 8: Results of ANOVA exploring differences in job characteristics and job satisfaction based on level of education

\begin{tabular}{|l|l|l|l|l|l|}
\hline & $\begin{array}{l}\text { Diploma level } \\
\text { and below } \\
(\mathbf{N}=\mathbf{1 9})\end{array}$ & $\begin{array}{l}\text { Undergraduate } \\
\text { degree } \\
(\mathbf{N}=\mathbf{8 0})\end{array}$ & $\begin{array}{l}\text { Masters } \\
\text { degree } \\
(\mathbf{N}=\mathbf{2 7})\end{array}$ & F (ANOVA) & Sign \\
\cline { 1 - 5 } & Mean & Mean & Mean & & \\
\hline Job autonomy & 12.16 & 13.15 & 12.52 & 0.677 & 0.510 \\
\hline Co-worker support & 14.21 & 15.36 & 14.37 & 1.565 & 0.213 \\
\hline Supervisory support & 10.58 & 11.58 & 11.30 & 1.377 & 0.256 \\
\hline Job variety & 9.79 & 11.24 & 11.22 & 2.626 & 0.076 \\
\hline Role stress & 23.58 & 18.58 & 18.70 & 5.615 & 0.005 \\
\hline Job satisfaction & 8.74 & 10.15 & 9.59 & 1.860 & 0.160 \\
\hline
\end{tabular}


The results of one-way ANOVA in Table 8 shows that, with the exception of role stress, the mean scores of job autonomy, co-worker support, supervisory support, job variety and job satisfaction did not differ significantly on the basis of level of education ( $p>0.05$ ).

The analysis has shown that there were statistically significant differences in the mean scores of role stress based on the different levels of education $(F=5.615, p=0.005)$. The results show that the means scores of role stress for respondents with Diploma level and below was significantly higher $(\mathrm{M}=23.58)$ than respondents with undergraduate degree $(M=18.58)$ and those with Masters degree $(M=18.70)$. This suggests that employees with Diploma and below experienced more role stress than employees with higher levels of education.

The above analyses shows that Hypothesis One that stated that "there are no differences in job characteristics and job satisfaction based on demographic characteristics, namely: age, gender, marital status, education, job tenure, position tenure and bank sector" was partially supported.

b) Results of Pearson Correlation analysis

$H_{0}$ 2: Job characteristics do not have any significant effect on job satisfaction

TABLE 9: Pearson's Correlation Analysis exploring the effect of job characteristics on job satisfaction

\begin{tabular}{|c|c|c|c|c|c|c|}
\hline & $\begin{array}{l}\text { Job } \\
\text { autonomy }\end{array}$ & $\begin{array}{l}\text { Co-worker } \\
\text { support }\end{array}$ & $\begin{array}{l}\text { Supervisory } \\
\text { support }\end{array}$ & Job variety & $\begin{array}{l}\text { Role } \\
\text { stress }\end{array}$ & $\begin{array}{l}\text { Job } \\
\text { satisfaction }\end{array}$ \\
\hline Job autonomy & 1 & $.310\left({ }^{* *}\right)$ & $.333\left({ }^{* *}\right)$ & $.218\left(^{*}\right)$ & .039 & $.211\left(^{*}\right)$ \\
\hline Co-worker support & $.310\left(^{* \star}\right)$ & 1 & $.285\left(^{* *}\right)$ & $.448\left(^{* *}\right)$ & -.097 & $.253\left({ }^{* \star}\right)$ \\
\hline Supervisory support & $.333\left({ }^{* \star}\right)$ & $.285\left(^{* \star}\right)$ & 1 & $.478\left({ }^{* *}\right)$ & $-.204\left(^{*}\right)$ & $.450\left({ }^{* *}\right)$ \\
\hline Job variety & $.218\left(^{*}\right)$ & $.448\left({ }^{* \star}\right)$ & $.478\left(^{* \star}\right)$ & 1 & $-.182\left(^{*}\right)$ & $.411\left(^{* \star}\right)$ \\
\hline Role stress & .039 & -.097 & $-.204\left(^{\star}\right)$ & $-.182\left(^{\star}\right)$ & 1 & -.124 \\
\hline Job satisfaction & $.211\left(^{*}\right)$ & $.253\left({ }^{* *}\right)$ & $.450\left(^{* \star}\right)$ & $.411\left(^{* \star}\right)$ & -.124 & 1 \\
\hline
\end{tabular}

${ }^{*} p<0.05 ;{ }^{* *} p<0.01$

Table 9 above shows the results of Pearsons correlation analysis to establish the strength and direction of the relationships among job characteristics factors and job satisfaction. The correlation analysis has shown that role stress did not have a significant effect on job satisfaction $(r=-0.124 p>0.05)$. The analysis has shown that job autonomy $(r=0.211, p<0.05)$, co-worker support $(r=0.253, p<0.01)$, supervisory support $(r=0.450, p<0.01)$ and job variety $(r=0.411, p<0.01)$ had significant, positive effect on job satisfaction. This suggests that job satisfaction increases when employees have freedom in performing their work, receive support from their colleagues and their supervisors, and perform variety of tasks. Thus, with the exception of role stress, Hypothesis Two which states that "job characteristics do not have any significant effect on job satisfaction" is rejected and the alternative hypothesis which states that job characteristics have significant effect on job satisfaction is accept

c) Results of multiple regression analysis

$H_{\mathrm{o}}$ 3: The combined effects of employee demographic characteristics and job characteristics do not have any significant effect on job satisfaction.

Table 10: Results of multiple regression analysis establishing the effects of job characteristics on employee job satisfaction

\begin{tabular}{|l|l|l|l|l|l|}
\hline & \multicolumn{2}{|l|}{ Unstandardized Coefficients } & $\begin{array}{l}\text { Standardized } \\
\text { Coefficients }\end{array}$ & $\mathrm{t}$ & Sig. \\
\hline & $\mathrm{B}$ & Std. Error & Beta $(\beta)$ & & \\
\hline (Constant) & 1.661 & 2.579 & & .644 & .521 \\
\hline Age of respondent & -.651 & .489 & -.147 & -1.331 & .186 \\
\hline Gender & .123 & .527 & .021 & .233 & .816 \\
\hline Marital status & .876 & .581 & .148 & 1.509 & .134 \\
\hline
\end{tabular}




\begin{tabular}{|l|l|l|l|l|l|}
\hline Education level & .048 & .366 & .011 & .132 & .895 \\
\hline Job tenure & -.007 & .364 & -.002 & -.018 & .985 \\
\hline Position tenure & -.391 & .419 & -.092 & -.933 & .353 \\
\hline Category of bank & .245 & .518 & .041 & .473 & .637 \\
\hline Job autonomy & .067 & .071 & .084 & .934 & .352 \\
\hline Co-worker support & .041 & .087 & .045 & .472 & .638 \\
\hline Supervisory support & .387 & .123 & .310 & 3.154 & .002 \\
\hline Job variety & .234 & .118 & .203 & 1.982 & .050 \\
\hline Role stress & -.011 & .042 & -.024 & -.272 & .786 \\
\hline
\end{tabular}

a Dependent Variable: Job satisfaction

Model Summary

\begin{tabular}{|l|l|l|l|l|l|}
\hline Model & $\mathbf{R}$ & R Square & Adjusted R Square & $\boldsymbol{F}$ (ANOVA) & Sign. level \\
\hline 1 & $.541(\mathrm{a})$ & .293 & .217 & 3.865 & 0.000 \\
\hline
\end{tabular}

a Predictors: (Constant), Role stress, Job tenure, Job autonomy, Gender of respondent, Category of bank, Education, Job variety, Marital status, Co-worker support, Supervisory support, Position tenure, Age of respondent

The model summary of the regression analysis in Table 10 shows that demographic characteristics and job characteristics accounted for $29.3 \%$ of the variance in job satisfaction among the respondents from commercial banks in Nakuru town (R square $=0.293$ ). The standardised beta coefficients indicate that supervisory support $(\beta=0.310, p$ $=0.002)$ and job variety $(\beta=0.203, p=0.050)$ were the only significant, positive predictors of job satisfaction. This suggests that job satisfaction increases when bank employees receive support from their supervisors and perform variety of tasks.

\section{DISCUSSION}

The main objective of the study was to determine the extent to which the demographic characteristics and job characteristics influenced job satisfaction among employees in commercial banks in Nakuru Town in Kenya.

Gender: The analysis showed that the mean scores of job characteristics and job satisfaction did not differ significantly among male and female bank employees. A possible explanation for these results is that both male and female bank workers are exposed to the same work environment and work-related factors characterised by adequate social support from both colleagues and supervisors, have freedom to make decisions and perform well-designed job with adequate variety and minimal role stress. This finding is contrary to studies that found significant gender differences in job satisfaction (Nestor \& Leary, 2010; Kipkebut, 2013).

Marital status: The analysis showed that married employees experienced more role stress than single employees. Studies have shown that, unlike single employees, married employees experience more stress than single employees due to work-family conflict, have to cope with heavy work demands which may require them to work long hours, have more financial demands and limited leisure time (Mathieu \& Zajac, 1990; Cetin, 2006). Similarly, Lambert \& Paoline (2008) reported that family roles caused problems at work for employees, resulting in decreased satisfaction with the job.

Age: The results have shown that older employees experienced more role stress than younger employees. Due to the stressful work conditions in banks characterised by long working hours, role overload and dealing with job insecurity arising from volatile market conditions, it is possible that older employees may experience more stress than younger employees as they may not have stamina to cope with role demands arising from the job (Bridger, 2009). Further, depression increases with age because of pressure at work due to uncertainty and increasing disillusionment with the job (Vanagas et al., 2004).

Education: The analysis has shown that employees with Diploma level of education and below experience more role stress than employees who have Undergraduate degrees and above. It is possible that Diploma holders and below earned less pay, performed jobs that were physically demanding requiring them to work long hours, jobs that lacked adequate variety and which availed them with less information about their roles resulting to role ambiguity as 
compared to employees with higher levels of education (Gunlu et al., 2010). Bader et al. (2013) noted that employees with lower levels of educationwere dissatisfied with their jobs since they received fewer promotional opportunities, had less earnings, and faced more job insecurity unlike employees with higher level of education. Consequently, employees with lower levels of education are more likely to experience role stress unlike employees with higher levels of education.

Bank sector: The results have shown that employees from foreign-owned banks were more satisfied with the relationships with their co-workers than employees from locally-owned banks. A possible explanation is that employees from foreign banks have experienced more training on the importance of teamwork and effective communication thus explaining the ability to relate with each other in a more effective way.

Job tenure: The analysis showed that employees who have worked in the banks for 16 years and above had more job autonomy than employees who have worked in the banks for 6 to10 years. It is possible that employees who had worked in the banks for 16 year and above had risen up the organisational ranks through promotions into positions that allow them freedom to make decision and to use their own initiatives to achieve results. The results also showed employees who have worked in the banks for 16 years and above had higher mean scores for co-worker and supervisory support than those who have worked for 11 to15 years. This suggests that employees who had worked in the bank for a long time had developed social support networks resulting in cordial relations with their colleagues and supervisors. Further, these employees were likely to be older, more experienced, skilful and had risen to managerial positions thus required minimal supervision from their supervisors.

Position tenure:The analysishas shown that employees, who have stagnated in the same position for 6 years and above, were more dissatisfied with supervisory support than those who have been in the same position for 5 years and below. This suggests that employees who had stagnated in the same position for 6 years and above felt unappreciated and thus developed negative work attitudes which was likely to affect their relationship with their supervisors. Similarly, employees who have stagnated in the same position for 6 years and above had less job variety as compared to employees who have been in the same position for 5 years and below. This suggests that employees who had been in the same position for 6 years and above had been doing the same work for a long time and had not received any promotion to more challenging positions resulting in negative work attitudes like boredom. Finally, respondents who have been in the same position for 6 years and above had lower mean scores for job satisfaction than those who have been in the same position for 5 years and below. Consistent with this study, Kipkebut (2013) found that job satisfaction declined when employees stagnated in the same position. This suggests employees who experienced career stagnation became frustrated and disillusioned with their jobs (Stevens et al., 1978; Hogan et al., 2006).

Job autonomy: The results showed that job autonomy had significant positive effect on job satisfaction. Consistent with this finding, Naqvi et al. (2013) found that job autonomy positively influenced job satisfaction since employees have freedom to perform their work and to make decisions, factors which are likely to make employees to feel that they are trusted by their organisations. Similarly, Kipkebut (2010) found that the opportunity to work independently with minimal supervision was important in shaping the job satisfaction of both academic and administrative employees in Kenyan universities.

Co-worker support: Consistent with previous studies, co-worker support had a significant positive effect on job satisfaction (Bonache, 2005; Lacy \& Sheehan, 1997). Kipkebut (2010) found that co-worker support was a significant positive predictor of job satisfaction among academic employees, which suggests that academics who had satisfactory professional interaction and collegial relations with their colleagues at work, and had confidence and trust in their colleagues, were more satisfied with their jobs than academics with poor co-worker support. Further, Gu \& Siu (2009) noted that support, encouragement, guidance and help from colleagues are likely to create a harmonious working environment thus enhance employee job satisfaction.

Supervisory support: Supervisory support had significant positive effect on job satisfaction. McCormack et al, (2006) reported that employees who had supervisory support had higher job satisfaction and organizational commitment than those who do not perceive themselves to be in supportive relationships with their supervisor. Supportive supervisors are likely to be considerate of the subordinates feelings and well-being. Gu \& Siu (2009) reported that supervisors who provide guidance and assistance to employees can help create a pleasant workplace that makes worker happy.

Job variety: Job variety had significant positive relationship with job satisfaction. Consistent with this finding, Lambert \& Paoline (2008) found that employees who performed jobs that require different tasks and provided them with stimulation resulted in positive outcomes such as job satisfaction. Further, Dean (2004) reported that jobs that are less challenging create boredom and a feeling of failure resulting in decreased job satisfaction.

\section{LIMITATIONS OF THE STUDY}

The findings of this study should be considered with a few limitations in mind. Firstly, self-report measures were used, which relied upon the honesty of the respondents and their emotional state at the time of filling the questionnaire. Secondly, the data collection for the present study was restricted to commercial banks in one town in Kenya. In order for the findings to be generalised to the entire banking industry in Kenya, the study should be expanded to include other locally-owned and foreign-owned banks in other towns in Kenya. Thirdly, the study relied on cross-sectional data, which was collected at one point in time. Future studies may carry out a similar research using longitudinal research design. 


\section{CONCLUSION AND RECOMMENDATION}

The purpose of this study was to establish the effect of demographic characteristics and job characteristics on employee job satisfaction in locally-owned and foreign -owned banks in Nakuru Town, Kenya. The results showed that job characteristics factors differed significantly based on demographic characteristics namely; marital status, level of education, age, position tenure, job tenure and bank sector. The correlation analysis showed that with the exception of role stress, all the job characteristics variables (namely, job autonomy, co-worker support, supervisory support, job variety) have significant positive effect on job satisfaction. Finally, the multiple regression analysis has shown that demographic characteristics were not significant predictors of job satisfaction. However, the analysis found that supervisory support and job variety were significant positive predictors of job satisfaction.

The study has confirmed that workers who perceive the bank as providing them with interesting and meaningful jobs, and a friendly and supportive environment are likely to have high levels of job satisfaction and therefore, turnover less (Rogers, Clow \& Kash, 1994). The study findings highlight the importance of having satisfied bank employees as a means of attaining success, efficiency, and customer satisfaction. Bank managers can ensure that job satisfaction increases by ensuring that employees have freedom in performing their work, receive support from their colleagues and their supervisors, and perform variety of tasks.

The study recommends that bank managers adopt various managerial interventions in order to create a pleasant and supportive work environment, in which job satisfaction will thrive. Participative management and supportive leadership, decreasing workload, redesigning jobs to make them more challenging and interesting and to enhance communication channels are examples of supportive managerial interventions. These supportive interventions will result in banks ability to utilize the full potential of their employees and in turn retain these employees at their current jobs to the end of their careers. Creating a supportive environment will also make employees to feel that they belong and are valued by their banks, colleagues and supervisors. Finally, it is expected that banks that understand their employees and are aware of what they need, can create an environment in which employees can thrive, be creative and productive, factors which are characteristics of successful banks.

\section{REFERENCES}

[1] Addae, H. M. \& Parboteeah, K. P. (2008) Role stressors and organizational commitment: public sector employment in St Lucia, International Journal of Manpower, Vol. 29, No. 6, pp. 567-582

[2] Al-Qarioti, M. Q. A. \& Al-Enezi, A. (2004) Organizational commitment of managers in Jordan: A field study. International Journal of Public Administration, Vol. 27, No. 5, pp. $331-352$

[3] Bader, H. A. M., Hashim, I. H. M. \& Zaharim, N. M. (2013) Job Satisfaction among Bank Employees in Eastern Libya, American International Journal of Social Science, Vol. 2, No. 1,pp. 30-44

[4] Greenberg, J. \& Baron, R (1996) Behaviour in Organizations. Paramus NJ: Prentice Hall publisher.

[5] Bemana,S., Moradi, H., Ghasemi, M., Taghavi, S. M. \& Ghayoor, A. H. (2013) The relationship among job stress and job satisfaction in municipality personnel in Iran world, Applied Sciences Journal, Vol. 22, No. 2, pp. 233-238

[6] Bonache, J. (2005) Job satisfaction among expatriates, repatriates and domestic employees: the perceived impact of international assignments on work-related variables, Personnel Review, Vol. 34, pp. 110-124

[7] Bowen, C. F., Radhakrishna, R. B. \& Keyser, R. (1994). Job satisfaction and commitment. Journal of Extension, 32, 1, http://www.joe.org/joe/1994june/rb2.php (Accessed $1^{\text {st }}$ March, 2014)

[8] Bridger, R.S. (2009). Introduction to Ergonomics. Third Edition, Taylor Francis Group

[9] Brough, P. \& Pears, J. (2004) Evaluating the influence of the type of social support on job satisfaction and work related, psychological well-being, International Journal of Organisational Behaviour, 8 (2), pp. 472 485

[10] Brown, D. \& Sargeant, M. A. (2007) Job satisfaction, organizational commitment, and religious commitment of full-time university employees, Journal of Research on Christian Education, 16, pp. 211-241

[11] Cetin, M. O. (2006) The relationship between job satisfaction, occupational and organizational commitment of academics. The Journal of American Academy of Business, 8 (1), pp. 78 - 88

[12] Clark, A., Oswald, A., \& Warr, P. (1996) Is job satisfaction U-shaped in age? Journal of Occupational and Organizational Psychology, 69 (1), pp. 57-81

[13] Curry, J. P., Wakefield, D.S., Price, J. L. \& Mueller, C. W. (1986) On the causal ordering of job satisfaction and organizational commitment. Academy of Management Journal, 29 (4), pp. 847-858

[14] Dean, A.M. (2004) Links between Organisational and Customer Variables in Service Delivery, International Journal of Service Industry Management, 15 (3-4), pp. 332-350

[15] Dessler G (2005) Human Resource Management. 10th ed. India: Prentice-Hall 
[16] Dhanapal, S., Alwie, S. B. M., Subramaniam, T. \& Vashu, D. (2013) Factors Affecting Job Satisfaction among Academicians: A Comparative Study between Gender and Generations, International Journal of Management Excellence, 2 (1), pp. 128-139

[17] Eskildsen, J. K., Kristensen, K. \& Westlund, A. H. (2004) Work motivation and job satisfaction in the Nordic countries, Employee Relations, 26 (2),pp. 122 - 136

[18] Fetsch, R. J., \& Kennington, M. S. (1997) Balancing work and family in Cooperative Extension: History, Effective Programs, and Future Directions, Journal of Extension, 35 (1). http://www.joe.org/joe/1997february/a2.php (Accessed on $3^{\text {rd }}$ March, 2014)

[19] Finnegan, R. P. (2010) Rethinking retention in good times and bad: Breakthrough ideas for keeping your best workers. Boston, Davies-Black publications

[20] Gentile, D.A \& McFarlin, D.B. (1991) Facet Importance and Job Satisfaction, Journal of Applied Psychology, 76, pp. 31- 39

[21] Griffeth, R. W., \& Hom, P. W. (2004) Innovative theory and empirical research on employee turnover. Greenwich, Conn: Information Age Publications.

[22] Griffin, R. W. \& Moorhead, G. (1997) Organizational Behaviour: Managing People and Organizations, $5^{\text {th }}$ Edn: Boston: HoughtonMifflin

[23] Gu, Z. \& Siu, R. C. S. (2009) Drivers of job satisfaction as related to work Performance in Macao casino hotels: An investigation based on employee survey, International Journal of Contemporary Hospitality Management, 21 (5), pp. 561-578

[24] Gunlu, E., Aksarayli, M. \& Percin, N. S. (2010) Job satisfaction and organizational commitment of hotel managers in Turkey, International Journal of Contemporary Hospitality Management, 22 (5), pp. 693717

[25] Hackman, J.R \& Lawler, E.E (1971). Employee Reactions to Job Characteristics. Journal of Applied Psychology, 55, pp. 259-286

[26] Hackman, J.R \& Oldham, G.R (1980). Motivation through the Design of Work. Test of a Theory. Organizational Behavior and Human Performance, 16, pp. 250-279

[27] Herzberg, F. (1966). Work and the nature of man. Cleveland: World Publications Company

[28] Hogan, N. L., Lambert, E. G., Jenkins, M. \& Wambold, S. (2006) The impact of occupational stressors on correctional staff organizational commitment: A preliminary study, Journal of Contemporary Criminal Justice, 22 (1), pp. 44-62

[29] Jegan, P. \& Gnanadhas, M. D. (2011) Job satisfaction of bank employees working with e-channels. Asian Journal of Business and Economics, 1 (11), pp. 1-8

[30] Judge, T., Bona, J., Thoresen, C. \& Patton, G. (2001) The Job Satisfaction - Job Performance Relationship: A Qualitative and Quantitative Review. Psychological Bulletin, 127 (4), pp. 376 - 407

[31] Khan, A. S. \& Khan, A. N. (2011) Investigating the demographic impacts on the job satisfaction of district officers in the province of KPK, Pakistan, International Research Journal of Management and Business Studies, 1 (3), pp. 068-075

[32] Kipkebut, D. J. (2010) Organisational Commitment and Job satisfaction in higher educational institutions: the Kenyan case, Unpublished Doctoral dissertation, Middlesex University, United Kingdom

[33] Kipkebut, D. J. (2013) The effects of demographic characteristics on organizational commitment, job satisfaction and turnover intentions: The case of employees in Kenyan Universities, Journal of Organisation and Human Behaviour, 2 (1), pp. 20-33

[34] Lacy, F. J. \& Sheehan, B. A. (1997) Job satisfaction among academic staff: An international perspective. Higher Education, 34, pp. 305 - 322

[35] Lambert, E. G. (2003) Justice in corrections: An exploratory study of the impact of organizational justice on correctional staff. Journal of Criminal Justice, 31, pp. 155- 168

[36] Lambert, E. G. (2004) The impact of job characteristics on correctional staff members. The Prison Journal, 84 (2), pp. 208 - 227

[37] Lambert, E. G. \& Hogan, N. (2009) The importance of job satisfaction and organizational commitment in shaping turnover intent: A test of a causal model. Criminal Justice Review, 34 (1), pp. 96-118

[38] Lambert, E. G., Hogan, N. L. \& Griffin, M. L. (2007) The impact of distributive and procedural justice on correctional staff job stress, job satisfaction and organizational commitment. Journal of Criminal Justice 35 (6), pp. 644-656 
[39] Lambert, E. G \& Paoline, A. E. (2008) The Influence of Individual, Job, and Organizational Characteristics on Job Satisfaction, and Organizational Commitment, Journal Criminal Justice Review, 33, pp. 541-564

[40] Locke, E. A. (1979) What is Job Satisfaction? Organizational Behaviour and Human Performance, Journal of Applied Psychology, 4, pp. 309-336

[41] Mathieu, J. E. \& Zajac, D. M. (1990) A review and meta-analysis of the antecedents, correlates and consequences of organizational commitment. Psychological Bulletin, 108, pp. 171-194

[42] Mbah, S. E. \& Ikemefuna, C. O. (2012) Job Satisfaction and Employees' Turnover Intentions in total Nigeria plc. in Lagos State, International Journal of Humanities and Social Science, 2 (14), pp. 275-287

[43] McCormack, D., Casimir, G., Djurkovic, N. \& Yang, L. (2006) The concurrent effects of workplace bullying, satisfaction with supervisor, and satisfaction with co-workers on affective commitment among schoolteachers in China, International Journal of Conflict Management, 17, pp. 316-331

[44] Meyer, J. P. \& Allen, N. P. (1997) Commitment in the workplace: Theory, research and application. Thousand Oaks, CA: Sage Publications

[45] Mowday, R., Porter, L. \& Steers, R. (1982) Employee-Organization Linkages: The Psychology of Commitment, Absenteeism, and Turnover. New York: Academic Press.

[46] Naqvi, S. M. M. R., Ishtiaq, M., Kanwal, N. \& Ali, M. (2013) Impact of job autonomy on organizational commitment and job satisfaction: the moderating role of organizational culture in fast food sector of Pakistan, International Journal of Business and Management, 8 (17), pp. $92-102$

[47] Nestor, P. I., \& Leary, P. (2000) The relationship between tenure and non-tenure track status of Extension faculty and job satisfaction. Journal of Extension, 38 (4), http://www.joe.org/joe/2000august/rb1.php (Accessed on ${ }^{5 \text { th }}$ March, 2014)

[48] Price, J. L. \& Mueller, C.W. (1986) Absenteeism and Turnover of Hospital Employees, JAI: Greenwich, CT.

[49] Riggs, K., \& Beus, K. M. (1993). Job satisfaction in Extension. Journal of Extension, 31 (2). http://www.joe.org/joe/1993summer/a5.php (Accessed on $3^{\text {rd }}$ March, 2014)

[50] Rogers, J. D., Clow, K. E. \& Kash, T. J. (1994) Increasing job satisfaction of service personnel. Journal of Services Marketing, 8 (1), pp. $14-26$

[51] Saari, M. L. \& Judge, A.T. (2004). Employee Attitudes and Job satisfaction. Human Resource Management. 43 (4), pp. 395-407

[52] Saleem, S., Majeed, S. \& Aziz, T. (2013) Determinants of job satisfaction among employees of banking industry at Bahawalpur, Journal of Emerging Issues in Economics, Finance and Banking, 1 (2), pp. 150162

[53] Seston, E., Hassell, K., Ferguson, J., \& Hann, M. (2009) Exploring the relationship between pharmacists' job satisfaction, intention to quit the profession, and actual quitting, Research in Social and Administrative Pharmacy, 5, pp. 121-132

[54] Shah, S. \& Jalees, T. (2004) An analysis of job satisfaction level of faculty members. Journal of Independent studies and Research, 2 (1), pp. 26-30

[55] Shrivastava, A \& Purang, P. (2009) Employee perception of job satisfaction: A comparative study of Indian banks, Asian Academy of Management Journal, 14 (2), pp. 65-78

[56] Sims, H. P., Szilagyi, A. D. \& Keller, R. T. (1976) The measurement of job characteristics, Academy of Management Journal, 19 (2), pp. $195-212$

[57] Sloan, M. M. (2012) Unfair treatment in the workplace and worker well-being: the role of coworker support in a service work environment, Work and Occupations, 39 (3), pp. 3-34

[58] Spector, P.E. (1997). Job Satisfaction: Application, Assessment, Causes and Consequences. Thousand Oaks, CA Sage

[59] Stevens, J. M., Beyer, J. M. \& Trice, H. M. (1978) Assessing personal, role and organizational predictors of managerial commitment, Academy of Management Journal, 21 (3), pp. 380-396

[60] Vanagas, G., Bihari-Axelsson, S. \& Vanagien, V. (2004) Do age, gender and marital status influence job strain development for general practitioner? Medicina (Kaunas), 40 (10), pp. 1014-1018

[61] Vidal, M., Valle, R. \& Aragon, M (2007 Antecedents of repatriates, job satisfaction and its influence on turnover intentions: evidence from Spanish repatriated managers, Journal of Business Research, 60, pp. $1272-1281$ 